\title{
THE DEVELOPMENT OF INDONESIAN LANGUAGE TEACHING MATERIALS BASED ON KNOWLEDGE INTEGRATION IN ISLAMIC HIGHER EDUCATION
}

\author{
Rahmiati, Azhar Arsyad, Muhammad Yaumi, Nur Asik, and Muhammad Nur Akbar Rasyid \\ Universitas Islam Negeri Alauddin Makasar \\ Jalan H. M. Yasin Limpo No. 36 Romang Polong, Gowa, Sulawesi Selatan \\ email: rahmiati.nur@uin-alauddin.ac.id
}

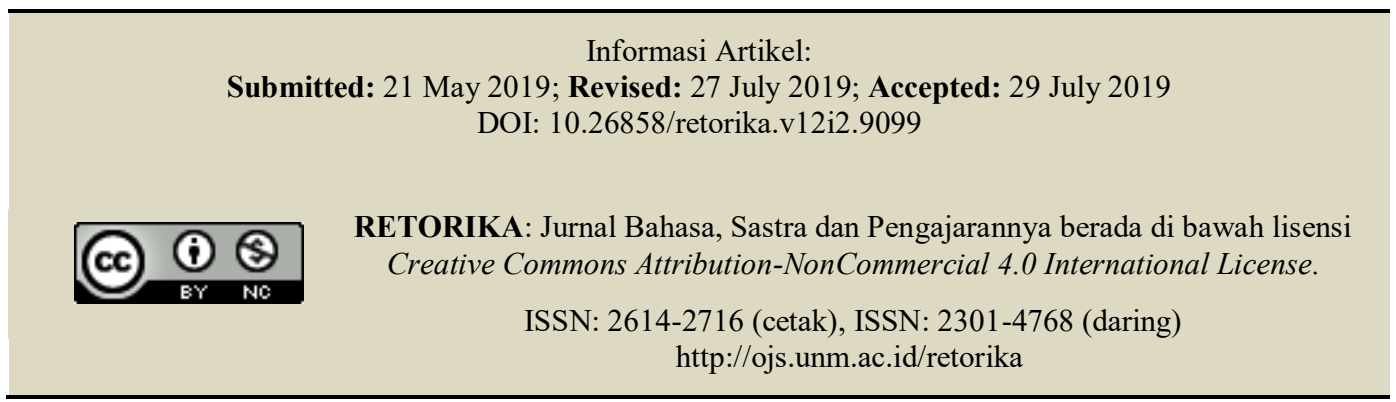

\begin{abstract}
The Development of Indonesian Language Teaching Materials Based on Knowledge Integration in Islamic Higher Education. This study aims at describing: (1) the reality and the needs for materials oriented towards knowledge integration, (2) the prototype and evaluation of the developed teaching materials. This is a Research and Development undertaken in UIN Alauddin Makassar involving 138 students, five lecturers, and two expert validators. The results show the currently used materials is not based on knowledge integration. Integration have been undertaken in the developed materials by including related verses or hadith, raising Islamic themes as reading materials and examples. The developed materials were evaluated by expert validators both content and design with the average score of 3.91 and 3.93 respectively and categorized as very good. The gain index for small and large groups is 0.71 and 0.72 respectively and categorized as high.
\end{abstract}

Keywords: Indonesian language, integration knowledge, material development, islamic education

\begin{abstract}
Abstrak: Pengembangan Bahan Ajar Bahasa Indonesia Berbasis Integrasi Keilmuan di Perguruan Tinggi Islam. Penelitian ini bertujuan untuk mendeskripsikan: (1) realitas dan kebutuhan akan materi yang berorientasi pada integrasi keilmuan, (2) prototipe dan evaluasi bahan ajar yang telah dikembangkan. Kajian ini adalah Penelitian dan Pengembangan yang dilakukan di UIN Alauddin Makassar dengan melibatkan 138 mahasiswa, lima dosen, dan dua validator ahli. Hasil penelitian menunjukkan bahan ajar yang saat ini digunakan tidak didasarkan pada integrasi keilmuan. Integrasi keilmuan dilakukan dalam bahan ajar yang dikembangkan dengan memasukkan ayat atau hadis terkait, mengangkat tema Islam sebagai bacaan dan contoh. Hasil evaluasi oleh validator baik konten dan desain terhadap bahan ajar tersebut dengan skor rata-rata 3,91 dan 3,93 dan dikategorikan sangat baik. Indeks gain untuk kelompok kecil dan besar masing-masing adalah 0,71 dan 0,72 dan dikategorikan tinggi.
\end{abstract}

Kata kunci: Bahasa Indonesia, integrasi keilmuan, pengembangan bahan ajar, pendidikan islam 
National standard curriculum design not only applies to Public Universities under the coordination of the Ministry of Research, Technology and Higher Education (KemenristekDikti), but also to Islamic Higher Education under the coordination of the Ministry of Religious Affairs of the Republic of Indonesia. The curriculum in PTKI is packaged in such a way as to be further presented in the teaching and learning process that is tailored to the needs of the institution in general and the needs of students in particular. For the purpose of development, even some Islamic Higher Education instituions in Indonesia, especially those that have the status of State Islamic Universities in the past few years have introduced a system of knowledge integration in higher education which has been realized in a scientific integrated curriculum, which combines general science with religious knowledge in teaching materials.

One effort to improve the quality of learning in higher education is by developing learning. Development is carried out in order to obtain useful products in the form of designs, methods and teaching materials prepared based on predetermined requirements (Putra, 2012:70). Materials developed must go through a validation process from various parties to determine the feasibility of the products produced.

The presentation of teaching materials that are in accordance with the needs of students shows how important teaching materials are as part of the curriculum. Therefore, it is necessary to do a directed, structured and systematic developmental process. Teaching materials must contain specific descriptions that will later become 'connecting bridges' between lecturers and students.

Various realities need to be observed related to Indonesian language teaching materials that are used in learning Indonesian language subject in higher education. The reality is that the needs of universities including PTKI with various scientific orientations and specifications have not been accommodated through Indonesian language learning books available in stores. While it is undeniable that teaching materials are necessary and must be developed at any time by adjusting to the needs and conditions of each college.

Based on the results of the researchers's initial observations in relation to the compulsory subject of Indonesian Language at UIN Alaud- din Makaassar, there are a number of issues that form the basis so that this research is very important to do. First, teaching materials used in Indonesian language learning have not met the needs of lecturers and students. Indonesian Language material which is supposed to be able to equip students with language skills has not achieved the expected results.

Secondly, based on the researchers' observation during the teaching of Indonesian subjects, the textbooks used in UIN Alauddin Makassar have not specifically indicated the existence of knowledge integration between general science and Islamic religious values as the mandate of transformation of IAIN to UIN Alauddin Makassar. In this case, the content offered is still general, and there is no content that shows the peculiarities of UIN Alauddin Makassar which reflects the concept of knowledge integration. As the result, teaching materials used by lecturers are not relevant and usually it was taught in accordance with lecturers' respective preferences; the material taught tends to be a repetition of the material at the previous level of education; the growing assumption of students who consider Indonesian language courses to be insignificant and only complement other subjects.

Basically, several studies related to the development of Indonesian Language teaching materials have been carried out at several higher education institutions in Indonesia both at Islamic Higher Education and Public Higher Education with different focus and research objectives. Some recent studies include research conducted by Muhammad Tohri who focused his research on developing Indonesian language teaching materials models with the aim of improving students' critical thinking skills at the Islamic Higher Education (PTAI) (Thohri, 2013). Research related to the development of Indonesian teaching materials was conducted by Purwati Ziska Diana who focused her research on the development of Indonesian Language textbooks based on collaborative learning for strengthening character education in existing State Universities in Indonesia (Diana, 2016). Another research on knowledge integration was also conducted by Nur Jamal who addressed the topic of Knowledge integration Models in Islamic Universities (Jamal, 2017). The results of other studies are the Qur'an Study and Knowledge integration: Case Study of Sunan Gunung Jati Bandung State Islamic University conducted by Iskandar in 
2016 (Iskandar, 2016). Knowledge integration in the developed Indonesian teaching materials proposed in the present study shows the novelty of this research compared to those previous studies.

Some Muslim scholars have views on knowledge integration. Integration is often raised by using the terms "Islamization of knowledge", naturalization of science, Islamic science and Islamic science. These concepts later became the basis for the emergence of the discourse of knowledge integration in Islamic Religious Colleges as a condition for making a transition from an institute-shaped educational institution to a university. Knowledge integration becomes the grand theme carried out by the State Islamic University (UIN) to develop its scientific concepts (Nata, 2005). The integration of science developed into the world of education is interpreted simply as a process of joining two elements with their own independency so that it becomes a unified and rounded whole (Poerdowasminto, 1986). Nevertheless, the results of the research conducted show that there are still many Muslims who views that science and religion are two independent things. Science is based on empirical data, while religion is based on trust and "faith". This direct separation was the reason for the emergence of debates among Muslim scholars including Ismail Raji Al-Faruqi, Syed Muhammad Naquib Al-Attas, Fazlur Rahman, and Ziauddin Sardar, who later rise the idea of "Islamization of science" (later called integration) (Mufid, 2013).

The problem that needs to be overcame by Islamic education institutions in an effort to ground the concept of integration of science and religion in the world of education is how to formulate its methodology. Efforts to integrate Islamic study material in general studies or vice versa, which are mostly carried out today, are integrating Islamic study material in the study of general sciences or vice versa, such as integrating Islamic study material, especially the Koran and Alhadits, integrated and interconnected with the field of general sciences studies (Aminuddin, 2019). Integration is carried out not only in the curriculum in general, but also touches up to teaching materials in the form of content integration. Others named it substantive integration (Simamora, 2017:55).

According to Banks, content integration is related to the extent to which teachers use examples and content from various cultures and groups to describe the concepts, principles, generalizations, and main theories in their fields or disciplines. Incorporating ethnic and cultural content into the subject must be logical, not artificial. Further, he explained that there are more opportunities for the integration of ethnic and cultural content in several subject areas than in others. In social studies, language arts, and music, more opportunities are available and enough for teachers to use ethnic and cultural content to describe concepts, themes, and principles. There are also opportunities to integrate multicultural content into mathematics and science. However, the opportunities are not as extensive as in social studies, language arts, and music (Banks, 2016). Based on this assumption, it can be concluded that the opportunity to integrate content in Indonesian language learning is more open as what will be conducted in this study.

The opportunity to develop teaching materials for Indonesian Language courses is based on the principle that the Sciences that will be developed by UIN are based on existing scientific nomenclature, consisting of fields of humanities, social sciences, and natural sciences as well as basic science fields with placing the AlQuran and Sunnah disciplines as its main studies, and Arabic for example as a tool to understand the sources of Islamic teachings, namely Quran and Sunnah which are studied crea-tively and hermeneutically so that they can be interpreted and developed continuously along with the times (Tim UIN Alauddin, 2015).

Knowledge integration at UIN Alauddin Makassar can be simply referred to the courses that must combine three components integratively. The discussion of topics in the field of fiqh, for example, is impossible to touch on contemporary issues such as neo-liberalism, human rights, nationalism, gender sensitivity, pluralism and multiculturalism in the environment without the help of biological sciences, sociology, anthropology, psychology, philosophy and so on (Tim UIN Alauddin, 2015).

As one of the Humanities science fields, Indonesian language teaching materials have a great opportunity to be developed by integrating science in them. Knowledge integration is not only limited to content, but also can be done through knowledge integration and pedagogic integration. The presence of knowledge integration-oriented Indonesian language teaching 
materials is expected to help students to produce good, systematic, directed, quality and integrated scientific work between mastering the general sciences and the application of Islamic religious values, which can be shown in character and personality in their interaction in society. Based on this, it is important to conduct a needs analysis of scientific integrated materials.

Needs analysis is an activity to identify materials that can be integrated into general science materials and religious knowledge. In this case, the hopes and needs to be achieved by students and lecturers in realizing the concept of integration for UIN Alauddin in all parts are necessary to be investigated. Analysis of these needs is crucial as it is used to develop teaching materials. By analyzing it, the product of teaching materials produced can be carried out effectively. Based on delineations above, the research was carried out relating to the development of Indonesia language teaching materials on the basis of knowledge integration.

\section{METHOD}

This is a research and development with the development model of Romiszowski. The model consists of four stages starting from the client system or needs analysis, instructional system, lesson plan, to material development (Romiszowski, 2013: 272). This study was conducted in one of the biggest Indonesian Islamic higher education, UIN Alauddin Makassar. Data were gathered through observation, document analyses, interviews and questionnaires. Needs analysis was carried out on five Indonesian language lecturers who are involved in both interviews and questionnaires. One hundred thirty eight students were involved as data sources for questionnaires selected through purposive sampling. In addition, the researchers selected eight of those students for interviews to gather deeper understanding of their needs. The interviews and questionnaires were mainly on the reality of the currently used teaching materials and their needs of integrated Indonesian language materials and strategic ways for knowledge integration. In addition, content analysis was carried out on five currently used teaching materials at UIN Alauddin Makassar to identify whether the currently used materials have been integrated.

This study also involved both content and design expert validators to review the validity of the newly developed Indonesian language teaching materials on the basis of knowledge integration. To measure the practicality and the effecttiveness of the product, the researchers involved 20 students in a small group and 40 students in large groups. These two groups were given pretest before they were taught using the newly developed books for seven meeting. After the treatment, they were given posttest to measure the gain index. To measure the practicality of the products, questionnaires were also distributed to students both in small and large groups after the treatment. The researchers used the formula of gain index proposed by Hake (1998) to measure the effectiveness. The following are the criteria to for the gain index: $\mathrm{g} \geq 0,70$ (high); $0,70>\mathrm{g}$ $\geq 0,30$ (medium); $\mathrm{g}<0,30$ (low).

\section{FINDINGS AND DISCUSSIONS}

\section{Findings}

\section{Needs Analysis of Lecturers}

Data related to the needs of lecturers for the Indonesian teaching materials oriented towards knowledge integration were obtained through questionnaires and interviews. The following is the data obtained from the questionnaires to determine the needs of lecturers for Indonesian teaching materials oriented towards knowledge integration.

Based on the data, information obtained from the statement "Indonesian language materials in textbooks have been oriented towards knowledge integration", Table 1 shows that the majority of respondents expressed disagreement and strong disagreement with the statement. This gives an initial indication that the Indonesian language teaching material applied at UIN Alauddin Makassar has not demonstrated knowledge integration with Islamic values. In the next statement on "Indonesian language materials integrated with Islamic values as a distinctive characteristic of the UIN Alauddin Makassar curriculum", all respondents agreed that the characteristics of UIN Alauddin curriculum with the theme of knowledge integration were applied in the teaching material given and was integrated with Islamic values. This is reinforced by the response the lectures when they were asked to how to integrate Islamic values into Indonesian language material. The majority agreed if "the 
Table 1. Lecturers' Need for Materials Oriented Towards Knowledge Integration

\begin{tabular}{|c|c|c|c|c|}
\hline No & Question & Answer & Total & $\%$ \\
\hline \multirow[t]{4}{*}{1} & \multirow{4}{*}{$\begin{array}{l}\text { Indonesian language material in textbooks has been } \\
\text { oriented towards knowledge integration }\end{array}$} & Strongly agree & - & 0 \\
\hline & & Agree & - & 0 \\
\hline & & Disagree & 3 & 60 \\
\hline & & Strongly disagree & 2 & 40 \\
\hline \multirow[t]{4}{*}{2} & \multirow{4}{*}{$\begin{array}{l}\text { Indonesian language material is presented } \\
\text { individually according to the topic of discussion }\end{array}$} & Strongly agree & - & 0 \\
\hline & & Agree & 1 & 20 \\
\hline & & Disagree & 3 & 60 \\
\hline & & Strongly disagree & 1 & 20 \\
\hline \multirow[t]{4}{*}{3} & \multirow{4}{*}{$\begin{array}{l}\text { Indonesian language material is integrated with } \\
\text { Islamic values as a distinctive feature of the UIN } \\
\text { Alauddin Makassar curriculum }\end{array}$} & Strongly agree & 4 & 80 \\
\hline & & Agree & 1 & 20 \\
\hline & & Disagree & - & 0 \\
\hline & & Strongly disagree & - & 0 \\
\hline \multirow[t]{4}{*}{4} & \multirow{4}{*}{$\begin{array}{l}\text { Indonesian language material is associated with } \\
\text { material from other disciplines }\end{array}$} & Strongly agree & 3 & 60 \\
\hline & & Agree & 2 & 40 \\
\hline & & Disagree & - & 0 \\
\hline & & Strongly disagree & - & 0 \\
\hline \multirow[t]{4}{*}{5} & \multirow{4}{*}{$\begin{array}{l}\text { Discussion topics are presented with the integration } \\
\text { of Islamic values by including relevant verses or } \\
\text { hadith }\end{array}$} & Strongly agree & 4 & 80 \\
\hline & & Agree & 1 & 20 \\
\hline & & Disagree & - & 0 \\
\hline & & Strongly disagree & - & 0 \\
\hline \multirow[t]{4}{*}{6} & \multirow{4}{*}{$\begin{array}{l}\text { Indonesian language material is integrated with Islam } \\
\text { by addressing Islamic discourse themes. }\end{array}$} & Strongly agree & 3 & 60 \\
\hline & & Agree & 2 & 40 \\
\hline & & Disagree & - & 0 \\
\hline & & Strongly disagree & - & 0 \\
\hline
\end{tabular}

discussion topics are presented in an integrated manner with Islamic values by incorporating relevant verses or hadith" and "Indonesian language material is integrated with Islam by adopting the themes of Islamic discourse". They also gave the same response to the statement "Indonesian material is related to material from other disciplines". They generally also agree if Indonesian material is associated with material from other scientific disciplines.

The results of the questionnaire were then followed up through interviews with lecturers to obtain comprehensive information on their needs. Based on the interviews, the following are some examples of interview quotes that show that knowledge integration has not been implemented in Indonesian language teaching materials.

I think that teaching material used in teaching Indonesian language has not been integrated with Islamic values. The material taught is only guided by available textbooks. I think it is good if there is an effort to create special teaching materials to accommodate knowledge integration as a characteristic of UIN. (Participant 2)
Regarding the expectations and needs of lecturers for the availability of Indonesian teaching materials oriented to knowledge integration, the majority of participants stated that they expected the existence of Indonesian language teaching materials that had been integrated with science in the form of integrating Islamic values into Indonesian learning.

I personally do hope that there will be Indonesian teaching materials specially made to accommodate knowledge integration as a distinctive feature of UIN Alauddin Makassar. (Participant 1)

When the lecturers were asked about the strategies that could be carried out in integrating Islamic values in Indonesian language teaching materials, participants conveyed several ways such as taking some Qur'anic propositions that are relevant to the topics discussed, and using Islamic themes as reading materials.

Knowledge integration in Indonesian language teaching material can be done by using some verses that are appropriate or addressing Islamic themes. (Participant 3) 


\section{Needs Analysis of Students}

To find out the needs of students for Indonesian scientific integrated learning materials, the researchers also distributed questionnaires to 138 students who had been selected as respondents and conducted interviews with eight students. The following is the results of questionnaire distributed to students.

Table 2 shows students' responses on their needs for materials oriented towards knowledge integration. On the statement that "Indonesian Language Materials in teaching books are oriented towards knowledge integration", there were $120(87 \%)$ students who disagree and strongly disagree with them. The remaining 18 people $(13.0 \%)$ agreed and strongly agreed that Indonesian language material was oriented towards knowledge integration. This data is in line with the data in the fifth and sixth statement related to the strategy or effort of knowledge integration in Indonesian language teaching materials. There were 122 respondents $(88.4 \%)$ who expressed their agreement if the topic of discussion was presented in an integrated manner with Islamic values by including relevant verses or hadith. While there were $16(11.6 \%)$ respondents expressed their disapproval. Almost the same distribution can be seen in the statement "Indonesian language material are integrated with Islam by adopting Islamic discourse themes". $124(89.9 \%)$ respondents agreed to this and the remaining 15 people $(10.1 \%)$ expressed their disagreement.

The students' needs were also obtained through interviews. The results of the interview were in line with the results from questionnaires. The following are some examples of interview quotes that show that knowledge integration has not been seen in the currently used Indonesian language teaching materials.

When we studied Indonesian language, ma'am, the materials were taken from the Indonesian textbooks. It's not a special book design for teaching Indonesian in UIN. (Participant 7)

Similar to lecturers, students also stated that they expected the existence of Indonesian language teaching materials that had been integrated with science in the form of integrating Islamic values into Indonesian teaching materials. According to them, doing something like that would be very beneficial. First, it is a characteristic of UIN Alauddin. Secondly, students

Table 2. Students Need for Materials Oriented Towards Knowledge Integration

\begin{tabular}{|c|c|c|c|c|}
\hline No & Questions & Answers & Total & $\%$ \\
\hline \multirow[t]{4}{*}{1} & \multirow{4}{*}{$\begin{array}{l}\text { Indonesian language material in textbooks has been } \\
\text { oriented towards knowledge integration }\end{array}$} & Strongly agree & 8 & 5.8 \\
\hline & & Agree & 10 & 7.2 \\
\hline & & Disagree & 33 & 23.9 \\
\hline & & Strongly disagree & 87 & 55.8 \\
\hline \multirow[t]{4}{*}{2} & \multirow{4}{*}{$\begin{array}{l}\text { Indonesian language material is presented } \\
\text { individually according to the topic of discussion }\end{array}$} & Strongly agree & 17 & 12.3 \\
\hline & & Agree & 20 & 14.5 \\
\hline & & Disagree & 53 & 38.4 \\
\hline & & Strongly disagree & 48 & 34.8 \\
\hline \multirow[t]{4}{*}{3} & \multirow{4}{*}{$\begin{array}{l}\text { Indonesian language material is integrated with } \\
\text { Islamic values as a distinctive feature of the UIN } \\
\text { Alauddin Makassar curriculum }\end{array}$} & Strongly agree & 78 & 56.5 \\
\hline & & Agree & 36 & 26.1 \\
\hline & & Disagree & 10 & 7.2 \\
\hline & & Strongly disagree & 14 & 10.1 \\
\hline \multirow[t]{4}{*}{4} & \multirow{4}{*}{$\begin{array}{l}\text { Indonesian language material is associated with } \\
\text { material from other disciplines }\end{array}$} & Strongly agree & 67 & 48.6 \\
\hline & & Agree & 49 & 35.5 \\
\hline & & Disagree & 15 & 10.9 \\
\hline & & Strongly disagree & 7 & 5.1 \\
\hline \multirow[t]{4}{*}{5} & \multirow{4}{*}{$\begin{array}{l}\text { Discussion topics are presented with the integration } \\
\text { of Islamic values by including relevant verses or } \\
\text { hadith }\end{array}$} & Strongly agree & 81 & 58.7 \\
\hline & & Agree & 41 & 29.7 \\
\hline & & Disagree & 9 & 6.5 \\
\hline & & Strongly disagree & 7 & 5.1 \\
\hline \multirow[t]{4}{*}{6} & \multirow{4}{*}{$\begin{array}{l}\text { Indonesian language material is integrated with Islam } \\
\text { by addressing Islamic discourse themes }\end{array}$} & Strongly agree & 78 & 56.5 \\
\hline & & Agree & 46 & 33.3 \\
\hline & & Disagree & 8 & 5.8 \\
\hline & & Strongly disagree & 6 & 4.3 \\
\hline
\end{tabular}


can also directly learn religious values because they are indeed UIN students. The following are some examples of excerpts from interviews with students regarding the expectation of the existence of Indonesian language teaching materials that specifically integrate Islamic values into Indonesian teaching materials.

I do agree, ma'am if Indonesian materials is also discussed some religious topics because we are in UIN (Participant 4)

Like lecturers, students were also asked their opinions about the strategies that can be done in integrating Islamic values in Indonesian language teaching materials. Participants also conveyed several ways such as linking topics with Qur'an and hadith propositions and using Islamic themes in reading.

The integration can be done by inserting some verses, Ma'am. (Participant 5)

The integration of Islamic values can be obtained by discussing some topics on Islam. (Participant 4)

\section{The Reality of the Currently Used Teaching Materials}

The results of document analysis and observations carried out by the researchers on Indonesian language teaching materials currently used at UIN Alauddin Makassar showed that teaching materials used by lecturers varied and the contents are alike. The researchers conducted content analysis of the five Indonesian language teaching materials currently used at UIN Alauddin Makassar, namely: Terampil Berbahasa Indonesia, Bahasa Indonesia di Perguruan Tinggi;
Bahasa Indonesia (Mata Kuliah Dasar Umum), Pengembangan dan Pembinaan Bahasa Indonesia; Terampil Menulis Karya Ilmiah (Petunjuk Praktis Penulisan Karya Ilmiah); as well as Cermat Berbahasa Indonesia di Perguruan Tinggi.

Student responses related to the reality of teaching materials used at UIN Alauddin Makassar using questionnaires to 138 students also showed similarity. The data can be seen in Table 3.

Table 3 shows that the teaching material used in UIN Alauddin Makassar has not shown knowledge integration especially the integration of Islamic values into Indonesian teaching materials. When students were asked "Indonesian language materials in textbooks oriented to knowledge integration", there were 125 (90.6\%) students stating not yet and only 13 (9.4\%) students stated already. This result was confirmed in the second item where when they gave a response regarding the statement "Indonesian material presented individually in accordance with the topic of discussion", there were $120(86.9 \%)$ who stated that they had and only 18 (13.1\%) stated that they had not. The results of this survey are in line with the results of document analysis and observations conducted by the researchers on five Indonesia language textbooks used at UIN Alauddin Makassar.

\section{The Product of Indonesian Language Teaching Materials Based of Knowledge Integration}

Based on the information gathered from students and lecturers, the researchers design the initial draft which accommodates their needs. There are two areas in which knowledge integration appear in the Indonesian language teach-

Table 3. The Reality of Teaching Materials Used at UIN Alauddin Makassar

\begin{tabular}{clccc}
\hline No & \multicolumn{1}{c}{ Questions } & Answer & Frequency & \% \\
\hline 1 & Indonesian language material in textbooks has been oriented towards & Yes & 13 & 9.4 \\
\cline { 2 - 4 } & knowledge integration & No & 125 & 90.6 \\
\hline 2 & $\begin{array}{l}\text { Indonesian language material is presented individually according to } \\
\text { the topic of discussion }\end{array}$ & Yes & 120 & 87.0 \\
\cline { 2 - 4 } & $\begin{array}{l}\text { Indonesian language material is integrated with Islamic values as a } \\
\text { distinctive feature of the UIN Alauddin Makassar curriculum }\end{array}$ & No & 18 & 13.0 \\
\cline { 2 - 4 } & $\begin{array}{l}\text { Indonesian language material is associated with material from other } \\
\text { disciplines }\end{array}$ & No & 118 & 14.5 \\
\hline \multirow{2}{*}{5} & $\begin{array}{l}\text { Discussion topics are presented with the integration of Islamic values } \\
\text { by including relevant verses or hadith }\end{array}$ & No & 18 & 13.0 \\
\cline { 2 - 4 } & $\begin{array}{l}\text { Indonesian language material is integrated with Islam by addressing } \\
\text { Islamic discourse themes }\end{array}$ & No & 17 & 121 \\
\cline { 2 - 4 } & Yes & 12.3 \\
\hline
\end{tabular}


ing materials. The first one is incorporating propositions in the form of verses of Qur'an and hadith that are relevant to the topic of discussion. Thus, there are several verses from Qur'an and hadith that the researchers put in the teaching materials as one strategy to integrate between religious and public knowledge.

This can be seen for example in the topic "The Position and Functions of Indonesian Language", the researchers put verse Al-Imran 103 which emphasizes the needs for human being to be united not to be separated. This verse is in line with one of the functions of Indonesian language which is language of unity. Another example can be found in the topic "Scientific Attitudes" which consists of several characteristics such as being curious about things, critical, honest and objective. Those characteristics are related to verses from Qur'an such Surah AlKahfi 106, Az-Zumar 33, and Al-Maidah 8.

The researchers also included Islamic themes in the readings or in assignments given to students. This was done in accordance with suggestions from students and lecturers regarding ways to integrate Islamic religious values into Indonesian language teaching materials. This is seen in the example of several kinds of paragraph in which the researchers raise Islamic themes such as Qur'an, shariah and aqidah. In addition, the researchers also included examples of sentences related to Islamic teaching when describing topic about types of sentences. For instance, the researchers use "Did you notice him who falsifies the Reckoning Day?" from surah Al-Ma'un and "So which of the favors of your Lord would you deny?" fom surah Ar-Rahman as examples of interrogative sentences. Besides, the researchers also used several Islamic teaching terms where it is relevant when describing about the topics. Those are ways of knowledge integration implemented in the development of Indonesian language teaching materials proposed in the present study.

\section{The evaluation of the Developed Indonesian Language Teaching Materials}

After revising the initial draft of Indonesian Language teaching materials based on input from reviewers who conducted limited assessments, the next stage the researcher submitted the developed materials for final validation by a validator whose expertise is in Indonesian Language and another validator whose expertise is Indonesian language learning design. Based on the results of the assessment from the first validator, the average score is 3.91 which is in the very good category. However, there are a number of suggestions from the first validator. First, the teaching material needs to be deepened, especially in analyzing and linking materials to one another. Second, the references needs to be supplemented with the latest, more recently published material.

The second validator whose expertise from teaching material design also provides an assessment of the product with the average score is 3.93 which is in the very good category. Similar to the first validator, he also suggests several things to improve the design of the teaching materials. There are some items that have not met the maximum score, namely displaying a good center point, placement of elements of a consistent layout based on patterns, illustrations and captions. All suggestions from the two validators have been used as the basis for conducting the final revision of Indonesian language teaching materials on the basis of knowledge integration before testing it in small and large groups to measure the effectiveness and practicality of the developed Indonesian teaching materials.

Table 4. The Average Pretest and Posttest Scores

\begin{tabular}{ccccc}
\hline Groups & Pretest & Posttest & Gain & Category \\
\hline Small & 42.15 & 83.20 & 0,71 & High \\
\hline Large & 41.65 & 84.63 & 0,72 & High \\
\hline
\end{tabular}

As shown in the Table 4, the results of the pretest and posttest for small group, the average pretest score is 42.15 . On the other hand, the average posttest score after the students were exposed to the teaching materials is 83.20. Based on the N-gain analysis suggested by Hake, the gain index result for the small group is 0.71 which is categorized as high. This results is confirmed by the results of the pretest and posttest conducted in large group. The results of the large groups showed that the average score of the students' pretest score is 41.65 . The average score of the posttest after they were given learning using Indonesian language teaching materials oriented towards knowledge integration is 84.63. The gain index for the large 
group is 0.72 , which is also categorized as high. Both of these results in small groups and large groups can be used as the basis for drawing conclusions that the developed Indonesian language teaching materials oriented towards knowledge integration are declared effective to assist students and lecturers in the process of learning Indonesian language.

\section{Discussion}

Based on the results of data analysis carried out in the previous section, it is known that the lecturers strongly approve the learning material of Indonesian language that scientifically integrated, both in the form of material that is related to other material and topics presented in an integration with Islamic values. This may influence the level of understanding gained by students in general, as in the characteristic of Islam applied by UIN Alauddin Makassar as an Islamic-based tertiary institution. The same thing was found by Helaluddin in his research where lecturers suggested prioritizing Islamic material in Indonesian language learning material in addition to other urgent themes such as health, sociopolitical issues, gender, and technology. It is suggested that in the discussion on discourse the specific themes raised are Islamic economics, banking, pawnshops and sharia insurance (Helaluddin, 2018).

In line with the expectations of the lecturers, needs analysis involving students also shows that they really need or strongly agree with the existence of Indonesian materials with knowledge integration. the integration meant here is that the integration between topics with one another, especially concerning the integration between Islamic content in learning Indonesian. In this case the strategies that can be carried out include raising Islamic discourse in paragraphs or readings given to students; synthetic material on Indonesian language with the arguments that originated from the Qur'an and hadith and connected the material. This concept of integration is expected to be able to equip students with characters and morality in the midst of society. It also can simultaneously influence the level of understanding that students get in general. This is in line with Dyah Sulistyowai's argument that reveals that the new paradigm of Indonesian language learning is integrative and communicative (Sulistyowati, 2015). This provides guidance that the expected direction of Indonesian language learning is integrative learning both with the material of other disciplines as well as from the values of Islamic teachings.

Based on the results of the needs analysis as well as document analyses, the researchers developed Indonesian language teaching materials on the basis of knowledge integration. There are several aspects that becomes the special characters of the newly developed Indonesian language teaching materials. First, integration of Islamic values have been done by including related verses or hadith. Second, knowledge integration has also been done by raising Islamic themes as reading materials or giving assignments in the exercises section to learn Islamic teaching. Including Islamic themes in students' reading materials is also undertaken by Udin and Fitria in their research about implementing Islamic characters in Indonesian language materials (2017:30). The integration of Islamic teaching can also be done by the inclusion of stories from Qur'an (Izzah \& Rafli, 2018). Similarly, Amelia (2012:13) proposes several ways of integrating Islamic values in language teaching which includes enclosing relevant Qur'an and/or hadith and mixing some Islamic expressions related to the given topic. These are also indicated in Sunarto's studies (2014). Banks (2016) suggests that knowledge integration can be done in three forms, namely: knowledge integration, content integration and pedagogic integration.

Knowledge integration is an integration carried out by combining Indonesian language material, general information (knowledge) and associated with the arguments contained in the Qur'an and hadith. Content integration is an effort made by lecturers to display examples and material to explain a concept, principles and theories in a scientific discipline. the lecturers can associate a material with cultural variations including different disciplines. In this case the social sciences including Indonesian have the possibilityty to be integrated with the science of religion. Whereas pedagogic integration means to combine knowledge of matter with religious values. Traditional pedagogics that limit the educational process by focusing on intellectual aspects are replaced with Pedagogic of hearts that support the socio-cultural life of the community. 
So, based on this, the development of Indonesia teaching materials with knowledge integration is possible by applying the three patterns of integration. It is expected that with the presence of the teaching material students will gain knowledge related to Indonesian and religion, students are expected to build attitudes, characters and good morals in their lives in accordance with Islamic values that they learn indirectly through Indonesian language teaching materials (Tilaar, 2004:11).

These knowledge integration in the developed teaching materials shows the novelty of this present research compared to previous studies which carried out knowledge integration in the form of content integration by specializing in certain topics. Knowledge integration which includes the integration of content, knowledge and pedagogy is very important given that the students of UIN Alauddin Makassar are prepared to answer the challenges of the open competition era by carrying out the concept of integration. The standards of knowledge integration in the performance of the Tridarma of Higher Education as contained in the UIN Alauddin Integration Guidelines include knowledge integration in the field of education, knowledge integration in the field of scientific research and integration in the field of community service (UIN Alauddin Makassar, 2017).

Having developed the Indonesian Language teaching materilas on the basis of knowledge integration, the researchers assess the products in terms of the validity, effectiveness, and practicality. The results of validity assessment from two expert validators shows that the product is valid in regard to the contents and designs with the average score of 3.91 and 3.93 respectively. These score are categorized as very good which means that the Indonesian language teaching materials developed in the present study can be used to teach Indonesian language at the university level. In addition, the researchers also have made some revision on the product for the final product based on the suggestions from two validators.

The researchers also tried out the developed Indonesian teaching materials in small and large group which consist of 20 and 40 students respectively. Those two groups were given pretest and posttest after the treatment to measure the gain index as the indicator of effectiveness proposed by Hake (1998). The gain index for small and large groups is 0.71 and 0.72 respectively. These results are categorized as high. These results are also confirmed in the measurement of practicality of the product gathered from the questionnaires distributed to students in small and large groups with the average of 81.21 and 81.67 respectively. These results indicates that the product developed in this study meets the criteria of validity, effectiveness and practicality which are essential to the development of teaching materials.

The results of this study have significant implications for Indonesian language teaching at UIN Alauddin Makassar. The results of this study provide a very strong indication of the importance of efforts to develop Indonesian teaching materials oriented towards knowledge integration. The product developed in the present study also have been proven to meet the criteria of validity, effectiveness, and practicality. Therefore, the university leadership and Indonesian language lecturers need to think of strategic steps in presenting and disseminating the newly developed Indonesian teaching materials oriented towards knowledge integration.

\section{CONCLUSION}

The results of research related to the reality of Indonesian language teaching materials and the needs analysis of Indonesian language teaching materials oriented towards knowledge integration at UIN Alauddin Makassar showed that the currently used teaching materials have not applied knowledge integration especially in the form of integration of Islamic values in Indonesian language teaching materials. Students and lecturers really expect the presence of an Indonesian textbook that is oriented towards knowledge integration, especially the integration of Islamic values into teaching materials.

Integration in Indonesian language teaching materials in the present study have been carried out by conducting three kinds of integration which are knowledge integration, content integration and pedagogic integration. The Indonesian language teaching materials developed in the present study have met the needs of students and lecturers and been developed on the basis of knowledge integration particularly integrating Islamic values and teaching in Indonesian language teaching materials. This newly developed 
teaching materials have also met the criteria of validity, effectiveness and practicality.

This study has significant implications for developing Indonesian language teaching materials oriented towards knowledge integration to meet the needs of students and lecturers and in line with the main mission of UIN Alauddin Makassar in particular and state Islamic universities in Indonesia in general which is knowledge integration between religion and science. Therefore, it is suggested to the relevant parties to follow up on the results of this study by disseminating the newly developed Indonesian teaching materials oriented towards knowledge integra-

\section{REFERENCES}

Amelia, R. 2012. Merancang Pembelajaran Bahasa Inggris Berbasis Pendekatan Islami. Jurnal Pemikiran Islam, 37(1), 8-15.

Aminuddin, M. Y. 2019. Perubahan Status Kelembagaan pada Perguruan Tinggi Agama Islam dalam Menghadapi Tantangan dan Peluang Pendidikan Islam di Indonesia. Ta'lim: Jurnal Studi Pendidikan Islam, 2(1): 22-44.

Banks, J. A. 2016. Multicultural Education: Characteristics and Goals. In J. A. Banks \& C. A. M. Banks (Eds.), Multicultural Educaion: Issues and Perpectives (9th ed.). River Street, NJ: John Wiley \& Sons, Inc.

Diana, P. Z. 2016. Pengembangan Buku Ajar Bahasa Indonesia Berbasis Pembelajaran Kolaboratif untuk Penguatan Pendidikan Karakter di Perguruan Tinggi. Program Studi Doktor Pendidikan Bahasa Indonesia, Universitas Sebelas Maret.

Hake, R. R. 1998. Interactive-Engagement versus Traditional Methods: A Six-Thousand-Student Survey of Mechanics Test Data for Introductory Physics Courses. American Journal of Physics, 66(1), 64-74.

Helaluddin. 2018. Analisis Kebutuhan Dalam Redesain Silabus (RPS) Mata Kuliah Bahasa Indonesia Di Perguruan Tinggi. Jurnal Penelitian Pendidikan Bahasa dan Sastra Indonesia, 4(1), 85-103. https://doi.org/10.22202/jg.2018.v4i1. 2464

Iskandar, S. 2016. Studi al Quran dan Integrasi Keilmuan: Studi Kasus UIN Sunan Gunung Jati Bandung. Jurnal Illmiah Agama Sosial Budaya, 1: 85-94.

Izzah, I., \& Rafli, Z. 2018. Needs Analysis of Indonesian Language Books Using Stories From Quran: New Innovation in Language Learning. In Proceedings of the 1st International Conference on Innovation in Education (ICoIE tion. The developed teaching materials have unique and different characteristics with currently used Indonesian language teaching materials at UIN Alauddin Makassar and Indonesian Islamic higher education in general due to several reasons. First, the teaching material have been developed based on the results of the needs analysis. Second, the teaching materials are based on knowledge integration, especially Islamic values and general knowledge that accommodate the needs of students of Islamic Higher Education under the auspices of the Ministry of Religious Affairs.

2018). Paris, France: Atlantis Press. Retrieved from https://www.atlantis-press.com/article/ 55912911

Jamal, N. 2017. Model-Model Integrasi Keilmuan Perguruan Tinggi Keagamaan Islam. Kabilah, 2(1): 90-101.

Mufid, F. 2013. Integrasi Ilmu-Ilmu Islam. Equilbrium, 1(1): 54-71.

Nata, A. 2005. Integrasi Ilmu Agama dan Ilmu Umum. Jakarta: PT. Raja Grafindo Persada.

Poerdowasminto, W. Y. S. 1986. Konsorsium Bahasa: Konsorsium Bahasa Indonesia. Jakarta: Balai Pustaka.

Putra, N. 2012. Research and Development. Penelitian dan Pengembangan: Suatu Pengantar. Jakarta: PT. Grafindo Persada.

Romiszowski, A. J. 2013. Developing Auto-Instructional Material: from Programmed texts to CAL and Interactive Video. Third Avenue, New York, NY: Routledge.

Simamora, N. A. 2017. Integrated Knowledge at State Islamic University of North Sumatera (UINSU), Medan, Indonesia. IOSR Journal of Humanities and Social Science, 22(5): 53-60.

Sulistyowati, D. 2015. Pembelajaran Bahasa dan Sastra Indonesia di Sekolah Dasar. In $\mathrm{S}$. Suwandi, S. Yuwana, P. Suratno, C. A. Woodrich, \& M. Rohmadi (Eds.) (pp. 423427). Surakarta, Indonesia.

Sunarto. 2014. The Integration of Islamic values in English Teaching and Learning at SDIT AlMumtaz Kota Pontianak. Universitas Negeri Yogyakarta.

Thohri, M. 2013. Pengembangan Model Bahan Ajar Bahasa Indonesia untuk Meningkatkan Keterampilan Berpikir Kritis Mahasiswa Perguruan Tinggi Agama Islam. Sekolah Pascasarjana, Universitas Pendidikan Indonesia.

Tilaar, H. A. R. 2004. Multikulturalisme: Tantangan- 
tantangan Global Masa Depan dalam Transformasi Pendidikan Nasional. Jakarta: Grasindo.

Tim UIN Alauddin. 2015. Mengukir Sejarah Peradaban 50 Tahun Milad Emas IAIN/UIN Alauddin Makassar. Makassar: Alauddin Press.

Udin, M. B., \& Fitria, K. L. 2017. The Implemen- tation of Islamic Character Through Developing Material of Indonesian Language in 3rd Grade of Islamic Elementary School. Madrosatuna: Journal of Islamic Elementary School, 1 (1): 23-36.

UIN Alauddin Makassar. 2017. Pedoman Integrasi Keilmuan UIN Alauddin Makassar. Makassar. 